\title{
MANAJEMEN RISIKO OPERASIONAL DAN PEMELIHARAAN TEMPAT PEMBUANGAN AKHIR (TPA) REGIONAL BANGLI DI KABUPATEN BANGLI
}

\author{
I W. Wedana Yasa ${ }^{1}$, I G. B. Sila Dharma ${ }^{2}$, I Gst. Ketut Sudipta ${ }^{2}$
}

\begin{abstract}
Abstrak: Untuk mendapatkan manfaat maksimal dan berkelanjutan dari dibangunnya TPA Regional Bangli perlu dilakukan kegiatan operasional dan pemeliharaan (OP). Penelitian ini bertujuan untuk mengidentifikasi berbagai risiko terutama risiko dominan yang dapat menghambat OP TPA, agar dapat dilakukan tindakan mitigasi dan menentukan kepemilikan risiko dari kegiatan tersebut. Data yang terkumpul dianalisis dengan metode deskriptif kualitatif melalui tahapan: identifikasi risiko, penilaian risiko, penanganan risiko, dan kepemilikan risiko.

Risiko yang teridentifikasi berjumlah 72, yang terdiri dari: 9 risiko (12,5\%) kategori tidak dapat diterima (unacceptable), 46 risiko (63,89\%) kategori tidak diharapkan (undesirable), 16 risiko $(22,22 \%)$ kategori dapat diterima (acceptable), dan 1 risiko $(1,39 \%)$ kategori dapat diabaikan (negligible). Risiko dominan (major risk) berjumlah 55 risiko (76,39\%), yakni hambatan untuk membentuk lembaga yang bertanggung jawab secara penuh dalam OP TPA Regional, terbatasnya alokasi dana baik dari pemerintah pusat, pemerintah daerah provinsi, dan pemerintah daerah kabupaten yang terintegrasi dalam TPA Regional, hambatan melakukan kerjasama antara pemerintah dengan pihak swasta, dan risiko lainnya. Mitigasi risiko dilakukan dengan menghindari risiko, mengurangi risiko, dan memindahkan risiko dimulai dari aspek institusi, regulasi, pembiayaan, serta program teknis dan non teknis. Jumlah kepemilikan risiko terbanyak diterima oleh badan pengelola TPA Regional Bangli.

Kata kunci : TPA, operasional dan pemeliharaan, mitigasi risiko
\end{abstract}

\section{OPERATING RISK AND MAINTENANCE MANAGEMENT OF BANGLI REGIONAL FINAL PLACE OF GARBAGE DISPOSAL 'TEMPAT PEMBUANGAN SAMPAH (TPA)' IN BANGLI REGENCY}

\begin{abstract}
To obtain the maximum and sustainable advantage it needs to carry out the operational and maintenance (OP) activities of TPA. It is necessary to maintain the Bangli Regional TPA so that it will give maximum and sustainable advantages. This study was aimed at identifying various major risks which may interfere with the TPA operating and maintenance so that mitigation can be done and to determine the risk ownership. The collected data were analyzed using descriptive qualitative method through the following stages: the risks were identified, the risks were evaluated, the risks were coped with, and the risk ownership could be identified.

The risks identified totaled 72 consisting of: $9(12.5 \%)$ risks which were under the unacceptable category, $16(22.22 \%)$ risks which were under the acceptable category, and $1(1.39 \%)$ risk which was under the negligible category. The major risks amounted to 55 risks $(76.39 \%)$, included the obstacle to establishing the institution which was fully responsible for the operating and maintenance of the Bangli Regional TPA, the limited amounts of funds allocated by the central government, the provincial government, and the regency governments which were integrated into the Regional TPA, the obstacle to creating an affiliation between the government and the private institutions, and other risks. The risk mitigation was done by avoiding risks, reducing risks, and transferring risks starting from the institutional, regulation and financial aspects, and technical and non technical problems. Most risk ownerships were the responsibility of the Bangli Regional TPA management.
\end{abstract}

Keywords: TPA, operating and maintenance, risk mitigation

\footnotetext{
${ }^{1}$ Mahasiswa Program Studi Magister Teknik Sipil, Program Pascasarjana Universitas Udayana.

${ }^{2}$ Dosen, Program Studi Magister Teknik Sipil, Program Pascasarjana Universitas Udayana.
} 


\section{PENDAHULUAN}

\section{Latar Belakang}

Tempat Pembuangan Akhir (TPA) Regional Bangli yang berlokasi di Dusun Bangklet, Desa Kayubihi, Kecamatan Bangli, Kabupaten Bangli dibangun untuk mengatasi masalah persampahan dan keterbatasan lahan yang dihadapi oleh empat kabupaten di Bali yakni Kabupaten Gianyar, Bangli, Klungkung dan Karangasem (anonim, 2006). TPA Regional Bangli direncanakan dapat menampung sampah dari empat kabupaten selama lebih dari 10 tahun masa layanan dengan sistem sanitary landfill.

Menurut Tchobanoglous (1993), TPA dengan sistem sanitary landfill merupakan sarana fisik yang digunakan untuk membuang sisa sampah padat perkotaan ke permukaan tanah di bumi dan ditutup pada setiap ahir operasi setiap harinya yang didesain dan dioperasikan secara sistematis untuk meminimalkan pengaruhnya terhadap kesehatan masyarakat umum dan lingkungan.

Namun disisi lain TPA dengan sistem sanitary landfill memerlukan biaya operasional dan pemeliharaan yang lebih mahal, standar operasional dan prosedur harian yang ketat untuk menghindari terjadinya penimbunan terbuka. Penimbunan terbuka pada lahan sanitary landfill menimbulkan dampak negatif, diantaranya: kerugian investasi pembangunan TPA karena memendeknya umur layanannya; sangat berpotensi menyebabkan pencemaran lingkungan seperti perkembangan vektor penyakit, polusi udara akibat gas yang dihasilkan sampah, polusi air akibat lindi (cairan sampah), dan estetika lingkungan yang buruk.

Untuk mendapatkan manfaat maksimal dan berkelanjutan dari dibangunnya TPA Regional Bangli maka perlu dilakukan analisis yang cukup mendalam terhadap berbagai risiko yang akan muncul dalam tahap operasional dan pemeliharaannya. Terutama risiko dengan kategori major risk sehingga dapat digunakan sebagai dasar dalam melakukan mitigasi untuk menekan akibat yang ditimbulkan oleh risiko tersebut.

\section{Rumusan Masalah}

Dari latar belakang di atas, permasalahan yang hendak dibahas dalam penelitian ini adalah :

1. Risiko apa saja yang teridentifikasi dan bagaimana penilaian (assessment) risiko dalam tahap operasional dan pemeliharaan tempat pembuangan akhir (TPA) regional Bangli?

2. Risiko-risiko apa saja yang termasuk katagori dominan (major risk) dalam tahap operasional dan pemeliharaan TPA regional Bangli?

3. Bagaimana mitigasi risiko yang dapat dilakukan untuk meminimalkan berbagai dampak negatif yang mungkin terjadi?

4. Bagaimana alokasi kepemilikan risiko (ownership of risk) jika risiko yang teridentifikasi benar terjadi?

\section{Tujuan Penelitian}

Tujuan dari penelitian ini adalah :

1. Untuk mengidentifikasi berbagai risiko dalam tahap operasional dan pemeliharaan tempat pembuangan akhir (TPA) regional Bangli.

2. Untuk mengetahui risiko apa saja yang termasuk kategori dominan (major risk) berdasarkan hasil identifikasi dan penilaian (assessment) pada tahap operasional dan pemeliharaan TPA regional Bangli.

3. Menentukan mitigasi risiko untuk meminimalkan berbagai dampak negatif yang mungkin terjadi.

4. Menentukan kepemilikan risiko, untuk program penanggulangan risiko (Risk mitigation).

\section{Manfaat Penelitian}

Manfaat penelitian adalah :

1. memberikan informasi risiko yang telah teridentifikasi dan dapat mengelompokkannya sesuai dengan sumber risiko pada tahap operasional dan pemeliharaan TPA Regional Bangli.

2. Dapat dijadikan dasar pengambilan keputusan oleh pihak-pihak terkait untuk mengatasi konsekuensi negatif yang terjadi dalam tahap operasional dan pemeliharaan TPA regional Bangli.

\section{Batasan Penelitian}

Risiko sisa (residual risk) setelah proses mitigasi tidak ditinjau. 


\section{KAJIAN PUSTAKA}

\section{Pengertian Risiko}

Risiko merupakan bagian yang tidak terpisahkan dari kehidupan, bahkan ada orang yang mengatakan bahwa tidak ada hidup tanpa risiko, terlebih lagi dalam dunia bisnis dimana ketidakpastian beserta risikonya merupakan sesuatu yang tidak dapat diabaikan begitu saja, melainkan harus diperhatikan secara cermat bila menginginkan kesuksesan.

Menurut Darmawi (2006), risiko dihubungkan dengan kemungkinan terjadinya akibat buruk (kerugian) yang tidak diinginkan atau tidak terduga. Hal ini didukung pendapat Djojosoedarso (1999), bahwa risiko mempunyai karakteristik : a. merupakan ketidakpastian atas terjadinya suatu peristiwa, b. Merupakan ketidakpastian yang bila terjadi akan menimbulkan kerugian.

Berdasarkan definisi di atas dapat diambil kesimpulan bahwa risiko adalah suatu pontensi kejadian yang dapat merugikan yang disebabkan karena adanya ketidakpastian atas terjadinya suatu peristiwa, dimana ketidakpastian itu merupakan kondisi yang menyebabkan tumbuhnya risiko yang bersumber dari berbagai aktivitas

\section{Manajemen Risiko}

Menurut Djojosoedarso

(1999),

Manajemen risiko adalah pelaksanaan fungsifungsi manajemen dalam penanggulangan risiko, terutama risiko yang dihadapi oleh organisasi, perusahaan, keluarga, dan masyarakat. Jadi mencakup kegiatan merencanakan, mengorganisir, menyususun, memimpin/mengkoordinir dan mengawasi program penanggulangan risiko.

Menurut Kerzner (1995), manajemen risiko adalah seperangkat kebijakan, prosedur yang lengkap yang dimiliki organisasi untuk mengelola, memonitor dan mengendalikan risiko yang mungkin muncul. Sistem manajemen risiko tidak hanya mengidentifikasi tapi juga harus menghitung risiko dan pengaruhnya terhadap proyek, hasilnya adalah apakah risiko itu dapat diterima atau tidak

\section{Identifikasi Risiko}

Menurut Flanagan dan Norman (1993) untuk dapat mengenali risiko secara komprehensif dapat dilakukan dengan mengenali dari sumbernya (source), kejadiannya (event), dan akibatnya (effect). Sumber risiko adalah kondisi-kondisi yang dapat memperbesar kemungkinan terjadinya risiko. Event adalah peristiwa yang menimbulkan pengaruh (effect) yang sifatnya dapat merugikan dan menguntungkan.

Lebih lanjut Godfrey

berpandangan bahwa dalam melakukan indentifikasi risiko terlebih dahulu diupayakan untuk menentukan sumber risiko itu sendiri secara komprehensif. Risiko dapat bersumber dari politis (political), lingkungan (environmental), perencanaan (planning), pemasaran (market), ekonomi (economic), keuangan (financial), proyek (project), teknik (tecnical), manusia (human), kriminal (criminal), dan keselamatan (safety).

Darmawi (2006) berpendapat bahwa melakukan identifikasi risiko merupakan proses penganalisaan untuk menemukan secara sistematis dan secara berkesinambungan risiko (kerugian yang potensial) yang menantang perusahaan.

\section{Klasifikasi Risiko}

Setelah risiko dapat teridentifikasi dilanjutkan dengan melakukan klasifikasi terhadap risiko, dengan tujuan untuk memudahkan melakukan perbedaan dan pemahaman terhadap risiko tersebut. Flanagan dan Norman (1993), mengemukan tiga cara untuk dapat mengklasifikasikan identifikasi risiko yakni dengan mengidentifikasi risiko berdasarkan konsekuensi risiko, jenis risiko dan pengaruh risiko.

Selanjutnya menurut Djojosoedarso (1999), melakukan pengukuran risiko, bertujuan untuk menentukan cara dan kombinasi cara -cara yang paling dapat diterima/ paling baik dalam penggunaan sarana penanggulangan risiko. Dimensi yang perlu diukur dalam pengukuran risiko adalah besarnya frekuensi kejadian yakni berapa kali terjadinya suatu kejadiaan dalam periode tertentu dan tingkat kegawatan (saverity) yakni sampai seberapa besar pengaruh dari suatu kerugian terhadap terhadap kondisi perusahaan.

Menurut Godfrey (1996) bahwa nilai risiko ditentukan sebagai perkalian antara kecenderungan/frekuenasi dengan konsekuensi risiko. Kecenderungan (likelihood) adalah peluang terjadinya kerugian yang merugikan, yang dinyatakan dalam jumlah kejadian pertahun. Sedangkan konsekuensi (consequences) merupakan besaran kerugian yang diakibatkan oleh terjadinya suatu kejadian yang merugikan yang dinyatakan dalam nilai uang. 


\section{Analisis Risiko}

Analisis risiko dapat dilakukan baik secara kualitatif maupun kuantitatif, dimana risiko harus diidentifikasi dan akibat (effect) harus dinilai atau dianalisis. Tujuan dari analisis risiko adalah membantu menghindari kegagalan dan memberikan gambaran tentang apa yang terjadi bila proyek yang dijalankan ternyata tidak sesuai dengan rencana.

\section{Penanganan (mitigation) Risiko}

Tindakan yang dilakukan untuk mengurangi risiko yang muncul disebut mitigasi/ penanganan risiko (risk mitigation).

Menurut Flanagan dan Norman (1993), Risk response adalah tanggapan atau reaksi terhadap risiko yang dilakukan oleh setiap orang atau perusahaan dalam pengambilan keputusan, yang dipengaruhi oleh pendekatan risiko (risk attitude) dari pengambil keputusan.

Tindakan yang dapat dilakukan dalam menangani risiko yaitu :

1. Menahan Risiko (Risk Retention)

Tindakan ini dilakukan karena dampak dari suatu kejadian yang merugikan masih dapat diterima (acceptable).

2. Mengurangi Risiko (Risk Reduction)

Mengurangi risiko dilakukan dengan mempelajari secara mendalam risiko tersebut, dan melakukan usaha-usaha pencegahan pada sumber risiko atau mengkombinasikan usaha agar risiko yang diterima tidak terjadi secara simultan.

3. Memindahkan Risiko (Risk Transfer).

Dilakukan dengan cara mengansuransikan risiko baik sebagian atau seluruhnya kepada pihak lain.

4. Menghindari Risiko (Risk Avoidance)

Dilakukan dengan menghindari aktivitas yang tingkat kerugiannya tinggi.

\section{Tempat Pembuangan Akhir (TPA)}

Menurut SNI 03-3241-1994, tempat pembuangan akhir sampah adalah sarana fisik untuk berlangsungnya kegiatan pembuangan akhir sampah berupa tempat yang digunakan untuk mengkarantina sampah kota secara aman. Sedangkan pengertian sampah menurut Standar Nasional Indonesia No.19-3964-1994 adalah limbah yang bersifat padat terdiri dari bahan organik dan bahan anorganik yang dianggap tidak berguna lagi dan harus dikelola agar tidak membahayakan lingkungan dan melindungi investasi pembangunan. Pengertian ini juga didukung oleh adanya Undang-Undang no 18 tahun 2008 yang menyebutkan sampah adalah sisa kegiatan sehari-hari manusia dan/proses alam yang berbentuk padat.

Sampah yang telah berada di TPA terutama sampah organik mengalami proses penguraian secara alami dengan jangka waktu panjang. Beberapa jenis sampah dapat terurai secara cepat, sementara yang lain lebih lambat, bahkan ada beberapa jenis sampah yang tidak berubah sampai puluhan tahun, misalnya plastik. Hal ini memberikan gambaran bahwa setelah TPA selesai digunakan pun masih ada proses yang berlangsung dan menghasilkan beberapa zat yang dapat mengganggu lingkungan. Diperlukan pengawasan terhadap TPA yang telah ditutup karena proses kimia dan biologis yang berlangsung menghasilkan hasil sampingan antara lain seperti gas dan lindi.

\section{TPA dengan Sistem sanitary landfill}

Beberapa prinsip dasar yang perlu diperhatikan jika menggunakan sistem sanitary landfill, yaitu :

a. Pihak pengelola harus dapat menjamin sampah diturunkan, ditutup dan dipadatkan secara efisien.

b. Air sampah (lindi) dan gas harus dikontrol dan dikeringkan untuk menjaga kondisi operasi yang terbaik dan melindungi kesehatan masyarakat serta lingkungan.

c. Pengelola tempat pembuangan akhir sampah harus bertanggung jawab terhadap operasional dan pemeliharaan landfill.

\section{Sarana dan Prasarana TPA dengan Sistem} Sanitary Landfill

Sarana penunjang TPA yang diperlukan guna menunjang kelancaran operasional TPA dengan sistem sanitary landfill, antara lain :

1. Prasarana jalan TPA yang dapat dikelompokan menjadi :

2. Prasarana drainase yang berfungsi untuk mengendalikan aliran limpasan air hujan sehingga dapat memperkecil masuknya air hujan ke timbunan sampah.

3. Fasilitas penerimaan yakni sebagai tempat pemeriksaan sampah yang datang, penimbangan, pencatatan data, dan pengaturan kedatangan truk sampah. 
4. Lapisan kedap air yang berfungsi untuk mencegah rembesan air lindi mengalir ke dasar TPA dan ke kolam pengolah lindi.

5. Lapisan pengaman gas yang terbentuk di TPA seperti gas karbon dioksida $\left(\mathrm{CO}_{2}\right)$ dan gas metan $\left(\mathrm{CH}_{4}\right)$ memiliki potensi besar dalam proses pemanasan global.

6. Fasilitas pengaman lindi untuk menghindari pencemaran terhadap air karena air yang terbentuk dalam timbunan sampah yang melarutkan banyak sekali senyawa yang ada sehingga memiliki kandungan pencemaran khususnya zat organik yang sangat tinggi.

7. Bahan penutup berupa tanah yang digunakan untuk memisahkan sampah dari lingkungan luar pada setiap hari kerja. Penutupan tanah pada lahan sanitary setiap harinya sangat penting untuk : menghindari gangguan lalat dan vektor penyakit lainnya, mencegah kebakaran dan asap, mengurangi polusi bau, mengurangi jumlah air yang masuk ke dalam sampah, mengarahkan gas menuju ventilasi keluar dari sanitary lanfill.

8. Alat berat yang digunakan di TPA berupa: bulldozer, excavator, dan louder. .

9. Penghijauan pada lahan TPA diperlukan untuk meningkatkan estetika lingkungan sebagai buffer zone sehingga mencegah bau dan lalat yang berlebihan.

10. Fasilitas penunjang untuk membantu pengoperasian TPA diantaranya : pemadam kebakaran, kesehatan dan keselamatan kerja, bangunan untuk kegiatan $3 \mathrm{R}$ (Reuse, Reduce, Recycle) serta peralatan penunjang lainnya.

\section{Operasional dan Pemeliharaan TPA dengan Sistem Sanitary Landfill}

Masalah yang berkaitan dengan pengelolaan TPA saat ini diantaranya : menurunnya kualitas TPA yang sebagian besar menjadi open dumping; timbulnya friksi antar daerah/sosial; menurunnya kapasitas pembiayaan daerah; pola pengelolaan TPA yang tidak bertanggungjawab sehingga menimbulkan korban jiwa seperti dalam kasus longsornya TPA Leuwigajah dan Bantar Gebang (anonim, 2006)

Untuk mendukung pencapaian sasaran pembangunan persampahan yang tegas dan realistis maka pemerintah pusat menyusun kebijakan dan strategi nasional pengembangan sistem pengelolaan persampahan yang tertuang dalam Peraturan Menteri Pekerjaan Umum Nomor 21/PRT/M/2006, yang dirumuskan sebagai berikut: pengurangan sampah semaksimal mungkin mulai dari sumbernya; peningkatan peran aktif masyarakat dan dunia usaha/swasta sebagai mitra pengelolaan; peningkatan cakupan pelayanan dan kualitas sistem pengelolaan; pengembangan kelembagaan, peraturan dan perundangan; serta pengembangan alternatif sumber pembiayaan.

Pengoperasian dan pemeliharaan TPA dengan sistem sanitary landfill membutuhkan pengawasan dan pengendalian untuk meyakinkan bahwa setiap kegiatan yang dilaksanakan di TPA sesuai dengan rencana yang telah ditentukan. Untuk dapat melakukan pengawasan dan pengendalian OP TPA dalam UU Republik Indonesia nomor 18 Tahun 2008 tentang Pengelolaan Sampah pada pasal 6 diatur tentang tugas pemerintah pusat dan pemerintah daerah diantaranya : menumbuhkembangkan dan meningkatkan kesadaran masyarakat dalam pengelolaan sampah; melakukan penelitian, pengembangan teknologi pengurangan dan penanganan sampah; memfasilitasi penyediaan prasarana dan sarana pengelolaan sampah dan manfaat hasil pengolahan sampah.

Wewenang pemerintah pusat dalam pengelolaan sampah diatur dalam UU Republik Indonesia nomor 18 Tahun 2008 pada pasal 7 diantaranya : menetapkan kebijakan dan strategi nasional; menetapkan norma, standar, prosedur, dan kreteria; memfasilitasi dan mengembangkan kerjasama antar daerah, kemitraan, dan jejaring. Selain itu juga wewenang pemerintah pusat adalah menyelenggarakan koordinasi, pembinaan dan pengawasan kinerja pemerintah daerah; dan menetapkan kebijakan penyelesaian perselisihan antar daerah.

Wewenang pemerintah provinsi dalam pengelolaan sampah diatur dalam UU Republik Indonesia nomor 18 Tahun 2008 pada pasal 8 diantaranya: menetapkan kebijakan strategi dalam pengolahan sampah sesuai dengan kebijakan pemerintah pusat; memfasilitasi kerjasama antar daerah dalam satu provinsi, kemitraan, dan jejaring dalam pengelolaan sampah. Wewenang pemerintah provinsi yang lain adalah menyelenggarakan koordinasi, pembinaan, dan pengawasan kinerja kabupaten/kota dalam pengelolaan sampah; dan memfasilitasi penyelesaian perselisihan pengelolaan sampah antar kabupaten/kota dalam provinsi.

Wewenang pemerintah kabupaten/kota dalam pengelolaan sampah diatur dalam UU 
Republik Indonesia nomor 18 Tahun 2008 pada pasal 9 diantaranya : menetapkan kebijakan dan strategi pengelolaan sampah berdasarkan kebijakan nasional dan provinsi; menyelengggarakan pengelolaan sampah skala kabupaten/kota sesuai dengan norma, standar, prosedur, dan kreteria yang ditetapkan oleh pemerintah. Selain itu wewenang pemerintah kabupaten adalah melakukan pembinaan dan pengawasan kinerja pengelolaan sampah yang dilaksanakan oleh pihak lain; menetapkan lokasi tempat penampungan sementara, tempat pengolahan sampah terpadu/ tempat pemrosesan akhir sampah; melakukan pemantauan dan evaluasi secara berkala terhadap tempat pemrosesan akhir sampah; menyusun dan menyelenggarakan sistem tanggap darurat pengelolaan sampah sesuai dengan kewenangannya.

Peran masyarakat seperti tertuang dalam UU RI No 18 tahun 2008 diantaranya : masyarakat dapat ikut dalam pengelolaan sampah yang dilakukan pemerintah melalui pemberian usul, pertimbangan, dan saran kepada pemerintah. Masyarakat juga dapat ikut dalam perumusan kebijakan pengelolaan sampah; pemberian saran dan pendapat dalam penyelesaian sengketa persampahan.

Menurut anonim ( 2006), TPA dengan sistem sanitary landfill harus dapat menjamin terlaksananya fungsi sistem pengumpulan dan pengolahan leachate, penanganan gas methan, pemeliharaan estetika sekitar lingkungan, pengendalian vektor penyakit, pelaksanaan keselamatan kerja, penanganan tanggap darurat bahaya kebakaran dan longsor. Secara teknis setiap data hasil pemantauan dan pengawasan serta catatan kegiatan perlu dirangkum dengan baik menjadi suatu laporan sehingga mudah memberikan gambaran mengenai kondisi pengoperasian dan pemeliharaan TPA.

\section{METODE PENELITIAN}

Jenis penelitian ini adalah deskriptif kualitatif yang dilakukan dengan metode studi kasus yaitu dengan menganalisis data dari suatu objek yang dijadikan kasus. Objek yang menjadi kasus dalam penelitian ini adalah TPA Regional Bangli.

Risiko yang mungkin terjadi pada tahap operasional dan pemeliharaan (OP) TPA Regional Bangli diidentifikasi dengan metode brainstorming atau wawancara dan survey.

Tahapan penelitian meliputi mencari informasi awal dalam upaya mengidentifikasi risiko untuk menyusun kuisioner penelitian.
Tahap identifikasi risiko disesuai dengan pandangan Godfrey (1996) dimulai dengan mencari informasi dengan jelas terhadap sumber (source) risiko, kejadian atau peristiwa (event) dan akibat (effect) risiko tersebut. Data sekunder juga diperoleh dari jurnal, penelitian sejenis dan studi literatur yang sudah ada sesuai dengan obyek penelitian.

Kuisioner yang telah disusun dari hasil identifikasi risiko pada pengkajian data sekunder disampaikan kepada para responden untuk diminta pendapatnya. Teknik pengumpulan data dalam penelitian ini mengunakan metode porpusive sampling, yaitu peneliti yang didasari atas kemampuan dan pengetahuan serta pertimbangan tertentu dapat menentukan pilihannya dalam memilih responden yang diyakininya mampu memberikan jawaban pada kuisioner sesuai topik penelitian (Sugiyono, 2010). Supaya para ahli/expertis dapat dianggap mewakili representatif dari populasi, maka reponden penelitian sekurang-kurangnya berasal dari unsur/dinas pemerintah pusat dan provinsi, pemerintah daerah kabupaten yang terkait dengan TPA Regional Bangli, serta unsur dari masyarakat tempat lokasi TPA Regional dengan jumlah sampel dua puluh dua responden.

Skala penilaian untuk mengukur kecenderungan (likelihood) terjadinya kejadian yang merugikan akibat risiko yang teridentifikasi yakni : 5 (sangat sering), 4 (sering), 3 (kadang-kadang), 2 (jarang), dan 1 (sangat jarang). Sedangkan skala yang digunakan untuk mengukur konsekuensi (consequences) risiko yakni : 5 (sangat besar), 4 (besar), 3 (sedang), 2 (kecil), dan 1 (sangat kecil).

Pengujian validitas dan reliabilitas alat ukur berupa kuisioner dilakukan dengan bantuan program SPSS versi 15. Nilai Pearson Product Moment hasil perhitungan program SPSS versi 15 disebut nilai $r$ hitung selanjutnya dibandingkan dengan nilai $\mathrm{r}$ tabel pada $\alpha=$ 0,$05 ;$ df $=\mathrm{n}-2$. Kaidah keputusan yang digunakan : jika $\mathrm{r}$ hitung > $\mathrm{r}$ tabel berarti valid, sebaliknya jika $r$ hitung $<r$ tabel berarti tidak valid.

Pengukuran reliabilitas dilakukan dengan teknik Alfa Conbrach, bila jawaban yang diberikan responden berbentuk skala seperti 13, 1-5, dan 1-7 atau jawaban responden yang menginterpretasikan penilaian sikap (Siregar, 2010). Kreteria yang digunakan sebagai ukuran menyatakan alat ukur reliabel yakni : skala 
pengukuran alat ukur memiliki nilai Alpha Cronbach minimal 0,7, nilai Cronbach Alpha if Item deleted lebih kecil dari nilai Alpha Cronbach keseluruhan, dan nilai Item-Total Correlation lebih besar dari 0,3.

Analisis tingkat penerimaan risiko (Risk Acceptability) tergantung nilai risikonya yang merupakan hasil perkalian antara kemungkinan (lilelihood) dengan konsekuensi (consequences). Tingkat penerimaan risiko memperhatikan nilai risiko seperti pada tabel 4.1.

Tabel 4.1. Skala Penerimaan Risiko

\begin{tabular}{|l|c|}
\hline \multicolumn{1}{|c|}{ Indikator Penerimaan Risiko } & Nilai Risiko \\
\hline Unacceptable(tidak dapat diterima) & $\mathrm{X} \geq 15$ \\
\hline Undesirable (tidak diharapkan) & $8 \leq \mathrm{X}<15$ \\
\hline Acceptable(dapat diterima) & $3 \leq \mathrm{X}<8$ \\
\hline Negligible (dapat diabaikan) & $\mathrm{X}<3$ \\
\hline
\end{tabular}

(Sumber: Godfrey,1996)

Penanganan risiko hanya dilakukan terhadap risiko dominan yakni risiko kategori Unacceptable dan Undesirable, dilanjutkan dengan menentukan kepemilikan tanggungjawab risiko (ownership of risk).

\section{HASIL DAN PEMBAHASAN}

Hasil penelitian mendapatkan jumlah risiko yang teridentifikasi berjumlah 72 risiko. Prosentase jumlah risiko menurut sumber risiko ditampilkan seperti pada Gambar 4.1. Hasil identifikasi tersebut menunjukan bahwa dalam OP TPA Regional Bangli sangat terkait dengan kegiatan teknis operasional TPA, dampak lingkungan serta alokasi biaya operasional.

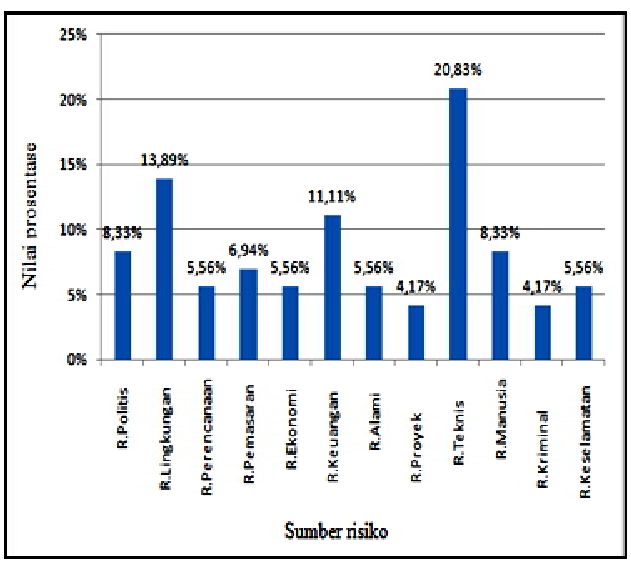

Gambar 4.1. Prosentase jumlah risiko berdasarkan sumber risiko

(Sumber : Hasil Analisis, 2012)
Berdasarkan hasil distribusi frekuensi dan modus jawaban responden terhadap frekuensi terjadinya risiko yang teridentifikasi dalam OP TPA Regional Bangli dapat dihitung prosentase frekuensi terjadinya risiko pada berbagai skala frekuensi seperti disajikan pada Gambar 4.2, dapat dijelaskan prosentase terbesar jawaban responden adalah skala 3 (kadang-kadang) yakni sebesar 40,28\%. Hal ini berarti sebagian besar responden beranggapan bahwa tingkat frekuensi kejadian munculnya risiko yang terdapat pada kuisioner berpotensi dapat terjadi dalam OP TPA Regional Bangli.

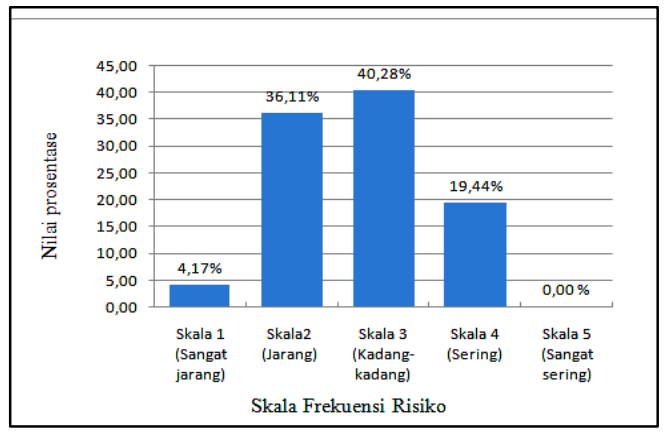

Gambar 4.2. Prosentase Frekuensi Terjadinya Risiko (Sumber : Hasil Analisis, 2012)

Distribusi frekuensi dan modus jawaban responden terhadap dampak/konsekuensi terjadinya risiko yang teridentifikasi dalam OP TPA Regional Bangli dapat disajikan pada gambar 4.3, dapat dijelalaskan prosentase terbesar jawaban responden adalah skala 4 (besar) yakni sebesar 47,22\%. Hal ini berarti sebagian besar responden beranggapan bahwa tingkat konsekuensi risiko yang terdapat pada kuisioner adalah besar.

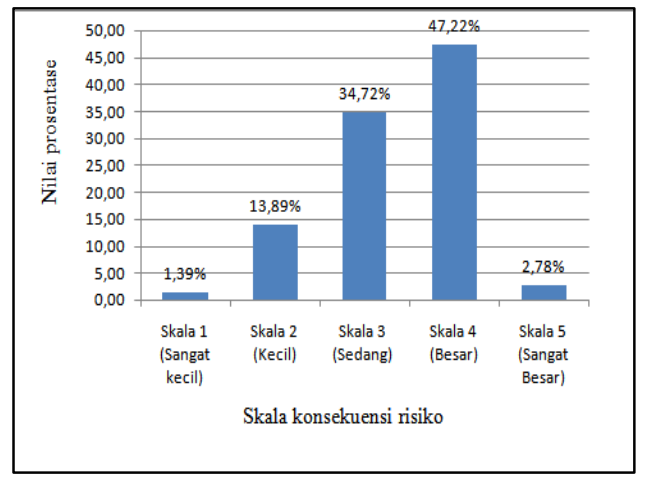

Gambar 4.3. Prosentase Konsekuensi Risiko (Sumber : Hasil Analisis, 2012)

Penerimaan risiko mempertimbangkan nilai risiko berdasarkan skala penerimaan risiko pada Tabel 4.1, dimana nilai risiko merupakan perkalian antara nilai frekuensi dengan nilai 
konsekuensi. Hasil distribusi penerimaan risiko untuk setiap sumber risiko dalam OP TPA Regional Bangli disajikan pada Tabel 4.2, dapat dijelaskan bahwa jumlah risiko dominan adalah 55 risiko yang terdiri dari kategori (unacceptable) sebanyak 9 risiko (12,50\%), dan kategori (undesirable) sebanyak 46 risiko $(63,89 \%)$. Sedangkan risiko tidak dominan berjumlah 17 risiko terdiri dari kategori (acceptable) sebanyak 16 risiko $(22,22 \%)$, dan kategori (neglibable) sebanyak 1 risiko $(1,39 \%)$.

Risiko dominan (major risk) memerlukan perhatian lebih lanjut karena risiko tersebut mempunyai dampak signifikan terhadap kelanjutan OP TPA Regional Bangli. Tindakan mitigasi terhadap risiko dominan didapat melalui analisis, brainstorming dan wawancara dengan para responden. Kepemilikan risiko bertujuan supaya semua risiko benar-benar berada dibawah kontrol pihak yang bertanggung jawab dan dapat ditangani dengan baik. Tanggungjawab kepemilikan risiko dilakukan berdasarkan pertimbangan : pihak mana yang mempunyai kontrol terbaik terhadap kejadian yang menimbulkan risiko, pihak mana yang dapat menangani risiko apabila risiko itu muncul, pihak mana yang mengambil tanggung jawab jika risiko tidak terkontrol, dan jika risiko diluar kontrol semua pihak diasumsikan sebagai risiko bersama.

Tabel 4.2. Distribusi Nilai Penerimaan Risiko

\begin{tabular}{|c|c|c|c|c|c|c|c|c|c|}
\hline \multirow{2}{*}{ No } & \multirow{2}{*}{ Sumber Risiko } & \multicolumn{2}{|c|}{ Uncceptable } & \multicolumn{2}{|c|}{ Undesirable } & \multicolumn{2}{|c|}{ Acceptable } & \multicolumn{2}{|c|}{ Negligible } \\
\hline & & \begin{tabular}{|l|}
$\mathrm{Jml}$ \\
\end{tabular} & $\%$ & $\mathrm{Jml}$ & $\%$ & $\mathrm{Jml}$ & $\%$ & $\mathrm{Jml}$ & $\%$ \\
\hline 1 & Risiko Politis & 2 & 2,78 & 4 & 5,56 & 0 & 0,00 & 0 & 0,00 \\
\hline 2 & Risiko Lingkungan & 0 & 0,00 & 8 & 11,11 & 2 & 2,78 & 0 & 0,00 \\
\hline 3 & Risiko Perencanaan & 0 & 0,00 & 2 & 2,78 & 2 & 2,78 & 0 & 0,00 \\
\hline 4 & Risiko Pemasaran & 1 & 1,39 & 4 & 5,56 & 0 & 0,00 & 0 & 0,00 \\
\hline 5 & Risiko Ekonomi & 0 & 0,00 & 1 & 1,39 & 3 & 4,17 & 0 & 0,00 \\
\hline 6 & Risiko Keuangan & 4 & 5,56 & 3 & 4,17 & 1 & 1,39 & 0 & 0,00 \\
\hline 7 & Risiko Alami & 0 & 0,00 & 2 & 2,78 & 1 & 1,39 & 1 & 1,39 \\
\hline 8 & Risiko Proyek & 0 & 0,00 & 3 & 4,17 & 0 & 0,00 & 0 & 0,00 \\
\hline 9 & Risiko Teknis & 1 & 1,39 & 9 & 12,50 & 5 & 6,94 & 0 & 0,00 \\
\hline 10 & Risiko Manusia & 1 & 1,39 & 4 & 5,56 & 1 & 1,39 & 0 & 0,00 \\
\hline 11 & Risiko Kriminal & 0 & 0,00 & 3 & 4,17 & 0 & 0,00 & 0 & 0,00 \\
\hline 12 & Risiko Keselamatan & 0 & 0,00 & 3 & 4,17 & 1 & 1,39 & 0 & 0,00 \\
\hline & Jumlah & 9 & 12,50 & 46 & 63,89 & 16 & 22,22 & 1 & 1,39 \\
\hline
\end{tabular}

(Sumber : Hasil Analisis 2012

\section{SIMPULAN}

1. Jumlah risiko yang dapat diindentifikasi dalam penelitian operasional dan pemeliharaan (OP) TPA Regional Bangli sebanyak 72 risiko, terdiri dari 9 risiko $(12,5 \%)$ dengan kategori tidak dapat diterima (unacceptable), 46 risiko $(63,89 \%)$ dengan kategori tidak diharapkan (undesirable), 16 risiko $(22,22 \%)$ dengan kategori dapat diterima (acceptable), dan 1 risiko (1,39\%) dengan kategori dapat diabaikan (negligible).

2. Risiko dominan (major risk) yang terjadi pada operasional dan pemeliharaan TPA Regional Bangli terdiri dari 55 risiko $(76,39 \%)$ yang terdiri dari 9 risiko $(12,5 \%)$ kategori Unacceptable dan 46 risiko $(63,89 \%)$ kategori Undesirable.

Risiko-risiko dominan yang termasuk kategori unacceptable yakni risiko hambatan untuk membentuk lembaga yang bertanggung jawab secara penuh dalam OP TPA Regional, hambatan melakukan kerjasama antara pemerintah dengan pihak swasta, biaya operasional pengangkutan sampah dari kabupaten yang lain menuju ke TPA Regional cukup mahal, terbatasnya alokasi dana pemerintah pusat, terbatasnya alokasi dana pemerintah daerah provinsi, terbatasnya alokasi dana dari masingmasing pemerintah daerah kabupaten yang terintegrasi dalam TPA Regional, dan risiko lainnya

3. Mitigasi risiko yang dapat dilakukan untuk menangani risiko dominan pada $\mathrm{OP}$ TPA Regional Bangli yakni dengan menghindari risiko, mengurangi risiko, dan memindahkan risiko. Mitigasi risiko dimulai dari aspek institusi, regulasi, pembiayaan, serta program teknis dan non teknis. Mendorong terwujudnya lembaga/badan layanan umum dalam OP TPA regional merupakan salah satu mitigasi dari aspek institusi. Dari aspek regulasi dapat dilakukan dengan mensosialisasikan peraturan persampahan dan sangsinya, melakukan kajian dan penetapan retribusi sampah dan dengan penetapan tugas pokok dan fungsi yang jelas bagi pihak-pihak yang terlibat dalam OP TPA regional.

4. Alokasi kepemilikan risiko dominan didistribusikan kepada para pihak yang memiliki peran dalam OP TPA Regional 
Bangli dengan jumlah kepemilikan risiko terbanyak diterima badan pengelola TPA Regional Bangli.

\section{UCAPAN TERIMA KASIH}

Ucapan terima kasih disampaikan kepada Bapak/Ibu responden penelitian ini atas bantuan dan kerjasamanya dalam memperoleh data-data yang dibutuhkan dan kepada semua pihak yang telah memberikan bantuan, dorongan, semangat, saran dan koreksi sehingga tesis ini dapat terselesaikan

\section{DAFTAR PUSTAKA}

Anonim. 1994. Tata Cara Pemilihan Tempat Pembuangan Akhir Sampah. Jakarta : Badan Standarisasi Nasional.

Anonim. 2006. Peraturan Menteri Pekerjaan Umum Nomor : 21/PRT/M/2006 Tentang Kebijakan Dan Strategi Nasional Pengembangan Sistem Pengelolaan Persampahan. Jakarta : Departemen Pekerjaan Umum Republik Indonesia.

Anonim. 2006. Laporan Akhir Perencanaan Teknis TPA Regional Bangli. Denpasar : Satuan Kerja Non Vertikal Tertentu Pengembangan Kinerja Pengelolaan Persampahan dan Drainase Provinsi Bali.

Anonim. 2008. Undang-Undang

Republik Indonesia Nomor 18 Tahun 2008 Tentang Pengelolaan Sampah. Jakarta : Kementerian Negara Lingkungan Hidup Republik Indonesia.

Darmawi, H. 2006. Manajemen Risiko. Cetakan kesepuluh. Jakarta : Bumi Aksara. Djojosoedarso, S. 1999. Prinsip-Prinsip Manajemen Risiko dan Ansuransi. Jakarta : Salemba Empat.

Flanagan, R. dan Norman, G. 1993. Risk Management and Construction. Cambridge : University Press.

Godfrey, P.S., Sir William Halcrow and Partners Ltd. 1996. Control of Risk A Guide to Systematic Management of Risk from Construction. Wesminster London : Construction Industry Research and Information Association (CIRIA).

Kezner, H. 1995. Project Management A System Approach to Planning Scheduling and Controlling. Fifth edition. New York : Van Nostrand Reinhold.

Setyaningrum, E. dan Sari, T. P. TPA Sanitary Landfill Kab. Bangli Menuju Pengelolaan Sampah Modern. 2010. Buletin Cipta Karya Edisi 04 Tahun VII : 22-25.
Siregar, S. 2010. Statistika Deskriptif Untuk Penelitian. Jakarta : Raja Grafindo Persada.

Sugiyono. 2010. Statistika Untuk Penelitian. Cetakan ke 16. Jakarta : CV. Alfabeta.

Tchobanoglous, G., Theisen, H., dan Vigil, S. 1993. Integrated Solid Waste Mangement. 1993. Singapore : McGraw-Hill, Inc. 